\title{
双缝隙喷嘴射流冲击正弦形状带材过程 压力系数的研究
}

\author{
梁波 $^{1}$ ，侯帅 ${ }^{2}$ ，白梅娟 ${ }^{2}$ ，刘建辉 ${ }^{2}$, 耿华 ${ }^{2}$, 刘继通 $^{2}$
}

(1.西北工业大学 自动化学院, 陕西 西安 710072；2.河北工程大学 信息与电气工程学院, 河北 邯単 056038)

\begin{abstract}
摘 要: 气垫炉广泛应用于铝带、铜带和硅钢的热处理过程, 而双缝隙喷嘴是气垫炉装置的核心部件。 研究悬浮带材表面的压力系数分布特性, 可以为气垫炉的高效高值生产奠定重要理论依据。研究了 $R e=48$ 194 12 048、高度 $H / D=1 \sim 3$ 、间距 $L / D=17.2$ 和正弦幅值 $A=0 \sim 30 \mathrm{~mm}$ 时, 双缝隙喷嘴射流冲 击正弦形状带材表面的压力系数分布规律。研究结果表明: 雷诺数 $R e$ 对压力系数 $C_{p}$ 以及主驻点与 第二驻点的压力系数差值影响并不明显; 压力系数 $C_{p}$ 随着 $H / D$ 的增大而减小, 而双缝隙喷嘴驻点处 的压力系数与非驻点处的压力系数差值随着 $H / D$ 的增大而增大。随着正弦幅值 $A$ 的增大, 主驻点位 置逐渐向 $x / D=0$ 移动; 压力系数 $C_{p}$ 随着正弦幅值 $A$ 的增加而减小; 随着 $L / D$ 的减小, 主驻点位置向 喷嘴的几何中心线移动, 第二驻点的压力系数逐渐增大。
\end{abstract}

\section{关 键 词: 气垫炉; 双缝隙喷嘴; 压力系数; 雷诺数}

\section{中图分类号:TF351}

文献标志码: A

气垫炉广泛应用于高端铝合金、硅钢和高精度 电子铜带的热处理和干燥过程, 其具有生产效率高 和产品表面质量好等优点 ${ }^{[1-4]}$ 。带材表面压力与喷 嘴出口动压的比值即压力系数, 是气垫炉的一个重 要参数 ${ }^{[5]}$ 。为气垫炉正常运行提供参考依据。

鉴于压力系数的重要性, 有学者研究了单缝隙 喷嘴射流冲击带材的压力系数分布规律 ${ }^{[6-8]}$, 也有 学者研究了双缝隙喷嘴射流冲击带材过程中的压力 系数分布规律 ${ }^{[9]}$ 。然而已有的关于双缝隙喷嘴射 流冲击带材的研究, 是针对喷嘴射流冲击水平形状 带材过程开展的研究。然而带材在气垫炉内漂浮 时, 带材的实际形状通常为正弦形状, 而不是水平形 状 ${ }^{[5]}$, 因此研究双缝隙喷嘴射流冲击正弦形状带材 过程的压力系数分布规律更符合实际情况, 且目前 尚未见到相关的研究工作。此外, 本论文将正弦形 状带材的幅度用正弦幅值 $A$ 来表示, 以往关于喷嘴 射流冲击水平形状带材过程中压力系数的研究可以 认为是喷嘴射流冲击正弦带材幅值 $A=0 \mathrm{~mm}$ 的一 种特殊情况, 因此本论文的研究内容对于压力系数
文章编号: 1000-2758(2019)03-0547-05
的研究更具有代表性和一般性。

\section{1 基本知识}

气垫炉在工作过程中, 喷嘴喷射气体到带材上 下表面,带材上下表面产生的压力差等于带材的重 力时, 带材悬浮在空中。双缝隙喷嘴是气垫炉常用 的一种喷嘴结构。带材表面的压力与喷嘴出口处动 压的比值, 即压力系数的分布情况, 该系数的具体表 达式

$$
C_{p}=\frac{p_{c}}{\frac{1}{2} \rho V_{0}^{2}}
$$

式中, $p_{c}$ 为带材下表面的压力, $V_{0}$ 为喷嘴出口处的 流体速度, $\rho$ 为流体密度。

对双㖓隙喷嘴射流冲击正弦形状带材做如下假 设: 假设正弦形状的正弦幅值为 $A$ 。水平形状带材 为正弦形状带材在幅值 $A=0 \mathrm{~mm}$ 的一种特殊情 况。带材两端距离喷嘴上表面的间距为 $H$, 双缝隙 
喷嘴的缝隙宽度为 $D, 2$ 个缝隙的中心间距为 $L$, 带 材的长度为 $W$ 。本文以图 1 中带材的最左端为坐标 原点, 见图 1 中的 $O$ 点。带材沿水平方向的位置用 $X$ 来表示。

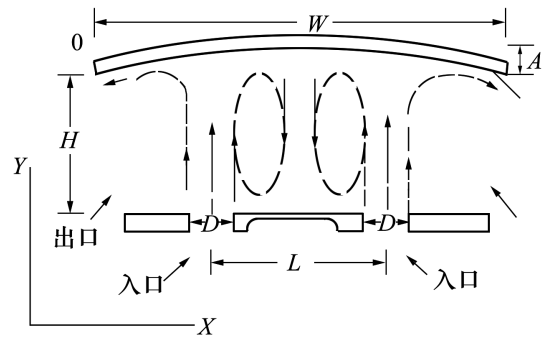

图 1 双缝隙喷嘴射流冲击原理图

本文针对图 1 中的最低高度 $H$ 、正弦幅值 $A$ 、喷 嘴间距 $L / D$ 对压力系数的影响规律开展了相关研 究工作。

\section{2 模型验证}

为了验证计算结果的正确性,本文基于已有的 气垫炉实验平台对仿真结果进行实验验证。该实验 装置的其他具体结构细节可参考文献 [ 12], 本文不 再赘述。

当无量纲 $H / D=3$, 带材正弦幅值 $A=0 \mathrm{~mm}$, 流 体的 $R e=48194$ 的情况下, 双缝隙喷嘴射流冲击正 弦形状带材过程的压力系数实测结果和模拟结果的 对比图如图 2 所示。

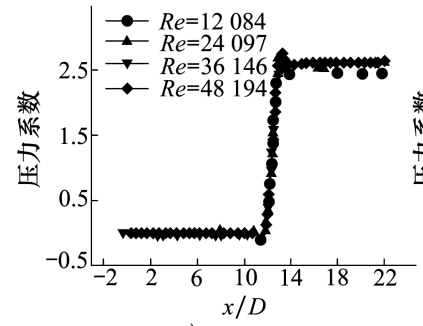

a) $A=0 \mathrm{~mm}$

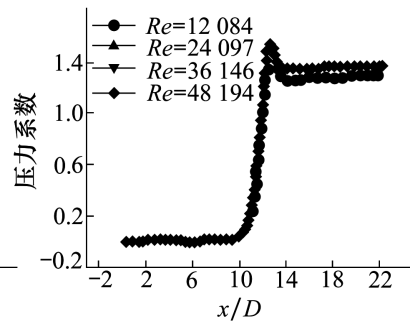

b) $A=10 \mathrm{~mm}$

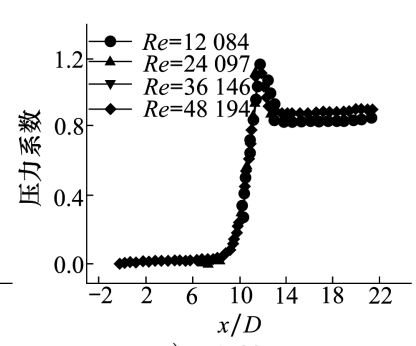

c) $A=20 \mathrm{~mm}$

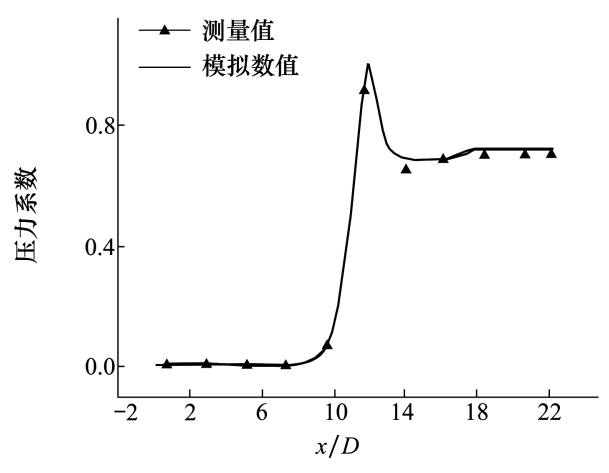

图 2 压力系数模拟与实验结果对比图

由于喷嘴射流过程中的流场分布情况沿双缝隙 喷嘴的几何中心线对称分布, 故本文只列出铝带几 何中心线一侧的表面压力系数分布曲线, 压力系数 的模拟计算结果如下: 从图 2 中可见本文的仿真结 果能够和真实实值较为接近, 本文所建立的模型能 够对实验值进行准确预测。

\section{3 实验结果分析}

由于喷嘴射流过程中的流场分布情况沿双缝隙 喷嘴的几何中心线对称分布, 故本文只列出铝带几 何中心线一侧的表面压力系数分布曲线, 压力系数 的模拟计算结果如下:

1) 雷诺数对压力系数的影响规律间距 $L / D=$ 17. 2 , 正弦幅值 $A=0 \mathrm{~mm}, 10 \mathrm{~mm}, 20 \mathrm{~mm}$ 和 $30 \mathrm{~mm}$, 雷诺数 $R e=12048,24097,36146$ 和 48194 时。图 3 为高度 $H / D=1$ 时压力系数的分布曲线。

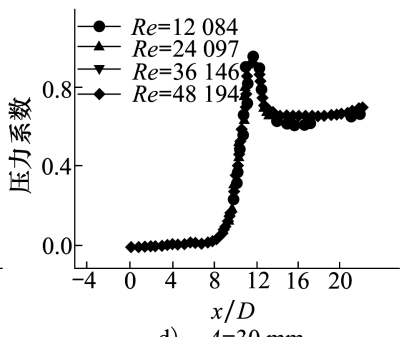

d) $A=30 \mathrm{~mm}$

图 $3 H / D=1$ 时压力系数曲线

由图 3 所示的压力系数的模拟结果可以发现在 不同高度 $H / D$ 下, 雷诺数 $R e$ 从 6024 增加到 36146 , 压力系数 $C_{p}$ 以及主驻点与第二驻点的压力 系数的差值变化并不明显。喷嘴的射流冲击效率并
不明显受 $R e$ 的影响。

2) 高度 $H / D$ 对压力系数的影响规律

无量纲参数 $L / D=17.2$, 带材正弦幅值 $A=0$ $\mathrm{mm}, 10 \mathrm{~mm}, 20 \mathrm{~mm}$ 和 $30 \mathrm{~mm}$, 无量纲参数 $H / D=1$, 
2,3 时, 图 4 为雷诺数 $R e=48194$ 时系数的分布 曲线。
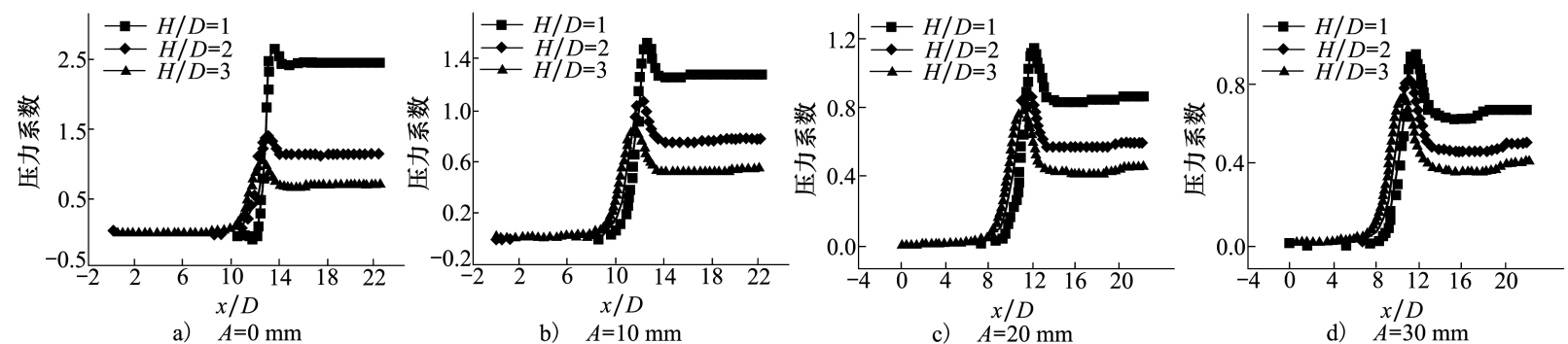

图 4 当 $R e=48194$ 时压力系数曲线

由图 4 可见压力系数 $C_{p}$ 随着 $H / D$ 的增大而减 小, 而双缝隙喷嘴驻点处的压力系数与非驻点处的 压力系数的差值随着 $H / D$ 的增大而增大。主驻点 的位置随着 $H / D$ 的增大而逐渐向 $x / D=0$ 移动; 压力 系数 $C_{p}$ 在 $x / D=6 \sim 8$ 的位置近似为零, 且随着 $H / D$ 的增大, 压力系数 $C_{p}$ 近似为零的位置也逐渐向 $x / D$ $=0$ 的位置移动。这是由于随着喷嘴与铝带材之间
的距离增加, 喷嘴上 2 个缝隙喷射出的气流相互影 响, 导致主驻点的位置向喷嘴边缘方向移动。

\section{3 ) 不同正弦幅值对压力系数的影响规律}

无量纲参数 $L / D=17.2$, 无量纲参数 $H / D=1$, 2,3 , 带材的正弦幅值 $A=0 \mathrm{~mm}, 10 \mathrm{~mm}, 20 \mathrm{~mm}$ 和 $30 \mathrm{~mm}$ 时, 当雷诺数 $R e=48194$ 时压力系数的模拟 结果如图 5 所示。

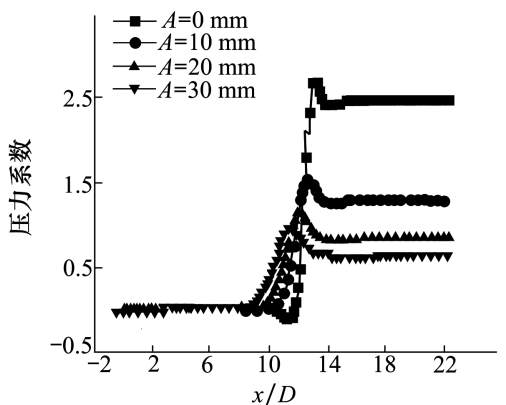

a) $H / D=1$

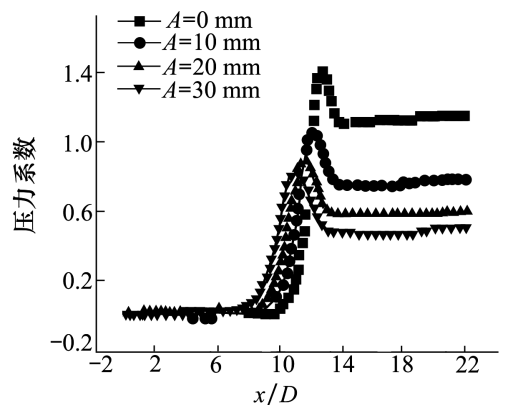

b) $H / D=2$

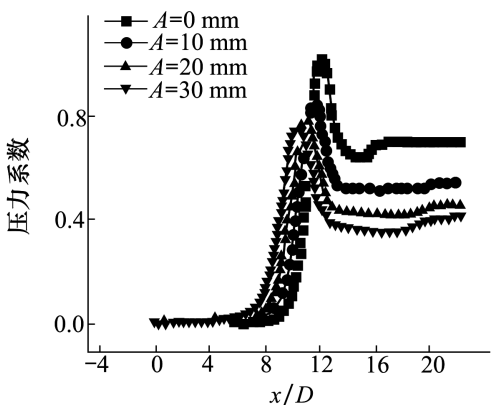

c) $H / D=3$

图 $5 R e$ 为 48194 时的 $C_{p}$ 曲线

由图 5 所示的正弦幅值对压力系数的模拟结果 可以发现在不同正弦幅值 $A$ 下, 压力系数的分布有 如下规律:

随着正弦幅值 $A$ 的增大, 主驻点处的位置逐渐 向 $x / D=0$ 移动; 压力系数 $C_{p}$ 在 $x / D=6 \sim 8$ 的位置 近似为零, 且随着正弦幅值 $A$ 的增大, 压力系数 $C_{p}$ 近似为零的位置也逐渐向 $x / D=0$ 的位置移动。这 是由于随着正弦幅值 $A$ 的增大, 喷嘴与铝带材之间 的空间增加, 喷嘴的 2 个缝隙射出的流场相互影响, 导致主驻点的位置向边缘方向移动。此外在无量纲 参数 $H / D=1 \sim 3$, 雷诺数 $R e=6024 \sim 36146$ 时, 压 力系数 $C_{p}$ 随着正弦幅值 $A$ 的增加而减小。该研究 表明正弦幅值的增大会增强 2 个缝隙喷嘴之间的干
扰作用, 导致双缝隙喷嘴冲击点向喷嘴外侧移动。

4) 缝隙间距对压力系数的影响规律

当雷诺数 $R e=48194$, 无量纲参数 $H / D=3$, 带 材的正弦幅值 $A=0 \mathrm{~mm}, 10 \mathrm{~mm}$, 无量纲参数 $L / D=$ $15,13,11$ 时,压力系数的模拟结果如图 6 所示。由 图 6 所示的喷嘴间距对压力系数的模拟结果可以发 现在不同的缝隙间距 $L / D$ 下, 压力系数的分布规律 如下:

随着 $L / D$ 的减小, 主驻点的位置向喷嘴的中心 线位置移动, 而且第二驻点的数值也逐渐的增大, 这 是由于 2 个缝隙喷射出的流场相互作用, 导致该区 域的压力系数升高。 


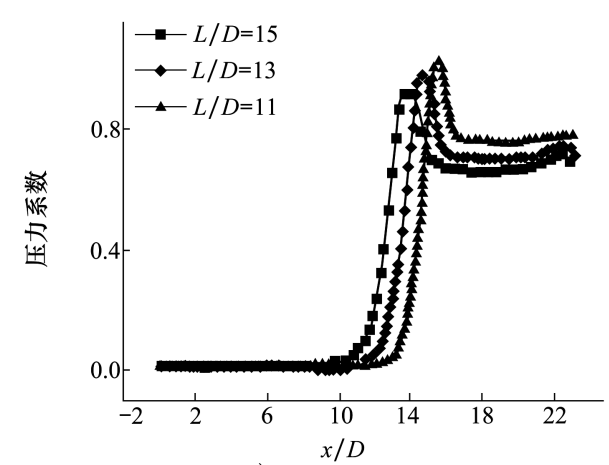

a) $A=0 \mathrm{~mm}$

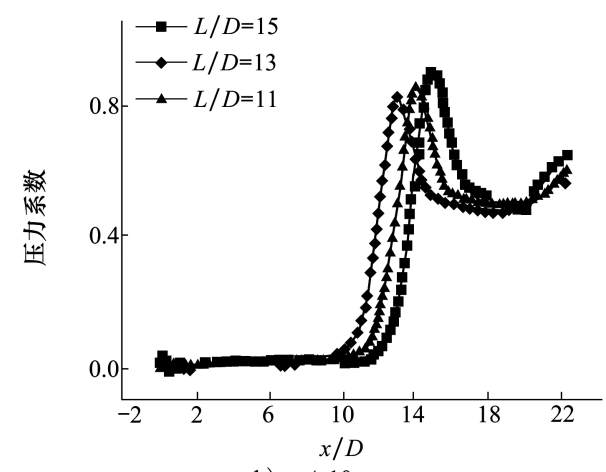

b) $A=10 \mathrm{~mm}$

\section{4 结 论}

本文研究了双缝隙喷嘴射流冲击正弦形状带材 过程中的压力系数分布情况。发现如下结论:

首先, 雷诺数 Re 对喷嘴射流效率影响并不大, 并且对 $C_{p}$ 以及主驻点与第二驻点的压力系数差值 影响并不明显;

其次, $H / D$ 的增大会导致喷嘴射流效率的降 低, 而双缝隙喷嘴驻点处的压力系数与非驻点处的 压力系数差值随着 $H / D$ 的增大而增大。

再次, 随着正弦幅值 $A$ 的增大, 2 个缝隙之间流 场的相互作用增强, 导致主驻点位置逐渐向 $x / D=0$ 移动。

最后,正弦幅值 $A$ 的增加会降低喷嘴的射流冲 击效率;随着 $L / D$ 的减小, 主驻点位置向喷嘴的几 何中心线移动。

图 6 当 $R e=48194$ 时不同情况的压力系数曲线

\section{参考文献:}

[1] WANG X, GUO M, CAO L, et al. Effect of Heating Rate on Mechanical Property, Microstructure and Texture Evolution of AlMg-Si-Cu Alloy during Solution Treatment $[\mathrm{J}]$. Materials Science \& Engineering A, 2015, 621: 8-17

[2] SHEN F, WANG B, YI D, et al. Effects of Heating Rate During Solid-Solution Treatment on Microstructure and Fatigue Properties of AA2524 T3 Al-Cu-Mg Sheet [J]. Materials \& Design, 2016, 104: 116-125

[3] 侯帅, 花福安, 白梅娟, 等. 气垫炉漂浮技术研究综述 $[J]$. 轻合金加工技术, 2018, 46(5): 6-14 HOU Shuai, HUA Fuan, BAI Meijuan, et al. Review of the Floating Technology of the Air Cushion Furnace[J]. Light Alloy Fabrication Technology, 2018, 46(5): 6-14 (in Chinese)

[4] 侯帅, 白梅娟, 花福安, 等. 大规格气垫炉试验平台机架的静态特性分析与设计 $[J]$. 工业炉, 2018, 40(3): 12-17 HOU Shuai, BAI Meijuan, HUA Fuan, et al. Analysis and Design on Static Characteristics of Large-Scale Air-Cushion Furnace Test Platform[J]. Industrial Furnace, 2018, 40(3): 12-17 (in Chinese)

[5] MORETTI P M. Lateral Deflections of Webs in Air-Flotation Ovens[J]. Journal of Applied Mechanics, 2004, 71(3): 314-320

[6] RAMEZANPOUR A, MIRZAEE I, FIRTH D, et al. A Numerical Heat Transfer Study of Slot Jet Impinging on an Inclined Plate [J]. International Journal of Numerical Methods for Heat \& Fluid Flow, 2007, 17(7) : 661-676

[7] RameZanpour A, SHIRVAni H, MiRZAEE I. Heat Transfer Modelling of Slot Jet Impinging on an Inclined Plate[J]. WIT Trans on Engineering Sciences, 2004, 46: 485-494

[8] BAYDAR E, OZMEN Y. An Experimental Investigation on Flow Structures of Confined and Unconfined Impinging Air Jets $[\mathrm{J}]$. Heat \& Mass Transfer, 2006, 42(4): 338-346

[9] ABDEL-FATTAH A. Numerical and Experimental Study of Turbulent Impinging Twin-Jet Flow $[\mathrm{J}]$. Experimental Thermal \& Fluid Science, 2007, 31(8): 1061-1072

[10] 侯帅, 李勇, 王昭东, 等. 气垫炉圆形喷嘴漂浮力及传热研究 $[J]$. 工业炉, 2013, 35(1) : 1-4 HOU Shuai, LI Yong, WANG Zhaodong, et al. Study on Round Nozzle' Floating Force and Heat Transfer Character of Air Cushion Furnace $[\mathrm{J}]$. Industrial Furnace, 2013, 35(1) : 1-4 (in Chinese)

[11] 侯帅, 王超, 王坤, 等. 气垫炉缝隙喷嘴传热特性研究 $[\mathrm{J}]$. 轻合金加工技术, 2013, 41(03): 45-48 
HOU Shuai, WANG Chao, WANG Kun, et al. Study on Heat Transfer Character From Slot Nozzle of Air Cushion Furnace[J]. Light Alloy Fabrication Technology, 2013, 41(03): 45-48 (in Chinese)

[12] HOU S, HUA F, LYU W, et al. Hybrid Modeling of Flotation Height in Air Flotation Oven Based on Selective Bagging Ensemble $\operatorname{Method}[\mathrm{J}]$. Mathematical Problems in Engineering, 2013(3) : 1-9

\title{
Study on Pressure Coefficient in Process of Double Slot Nozzle Jet Impingement on Sinusoidal Colliding Strip
}

\author{
LIANG Bo $^{1}$, HOU Shuai ${ }^{2}$, BAI Meijuan ${ }^{2}$, LIU Jianhui ${ }^{2}$, GENG Hua ${ }^{2}$, LIU Jitong ${ }^{2}$ \\ (1.School of Automation, Northwestern Polytechnical University, Xi'an 710072, China; \\ 2.School of Information and Electrical Engineering, Hebei University of Engineering, Handan 056038, China)
}

\begin{abstract}
Air cushion furnace is widely used in the heat treatment process of aluminum strip, copper strip and silicon steel, and the double slot nozzle is the core part of the air cushion furnace device. Studying the distribution characteristics of the surface pressure coefficient of the strip during the suspension process could provide important theoretical references for the high-efficiency and high-value production of the air-cushion furnace. In this paper, the distribution of pressure coefficients is studied under the conditions of $R e=48194 \sim 12048$, high $H / D=1 \sim 3$, spacing $L / D=17.2$ and sinusoidal amplitude $A=0 \sim 30 \mathrm{~mm}$. The results show that with the decrease of $L / D$, the position of the main stop point moves to the center line of the nozzle, and the value of the second stop point increases gradually, and with the increase of the sinusoidal amplitude $A$, the position of the main stop point moves gradually to $x / D$ $=0$. The pressure coefficient $C_{p}$ decreases with the increase of sinusoidal amplitude $A$, the pressure coefficient $C_{p}$ decreases with the increase of $H / D$, and the difference between the pressure coefficient at the stationary point of the double-slot nozzle and the pressure coefficient at the non-stationary point increases with the increase of $H / D$. This study provides an important theoretical basis for the design of double slot nozzles in air cushion furnace.
\end{abstract}

Keywords : air cushion furnace; dual-slot nozzle; pressure coefficient; Reynolds number 